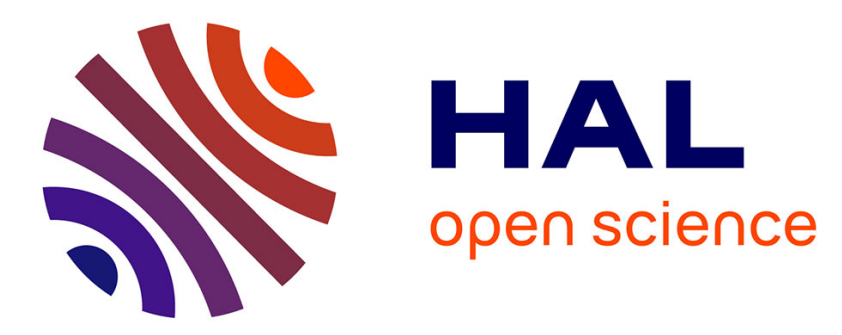

\title{
Reduced graphene oxide/polyethylenimine based immunosensor for the selective and sensitive electrochemical detection of uropathogenic Escherichia coli
}

Roxana Jijie, Karima Kahlouche, Alexandre Barras, Nao Yamakawa, Julie Bouckaert, Tijani Gharbi, Sabine Szunerits, Rabah Boukherroub

\section{To cite this version:}

Roxana Jijie, Karima Kahlouche, Alexandre Barras, Nao Yamakawa, Julie Bouckaert, et al.. Reduced graphene oxide/polyethylenimine based immunosensor for the selective and sensitive electrochemical detection of uropathogenic Escherichia coli. Sensors and Actuators B: Chemical, 2018, 260, pp.255 263. 10.1016/j.snb.2017.12.169 . hal-01925128

\author{
HAL Id: hal-01925128 \\ https://hal.science/hal-01925128
}

Submitted on 2 Dec 2019

HAL is a multi-disciplinary open access archive for the deposit and dissemination of scientific research documents, whether they are published or not. The documents may come from teaching and research institutions in France or abroad, or from public or private research centers.
L'archive ouverte pluridisciplinaire HAL, est destinée au dépôt et à la diffusion de documents scientifiques de niveau recherche, publiés ou non, émanant des établissements d'enseignement et de recherche français ou étrangers, des laboratoires publics ou privés. 


\section{ToC image:}

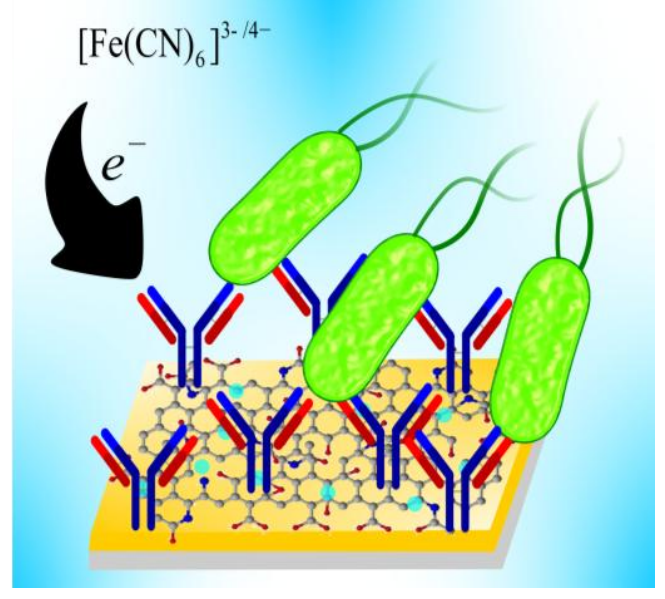

Reduced graphene oxide/polyethylenimine based immunosensor for the selective and sensitive electrochemical detection of uropathogenic Escherichia coli

Roxana Jijie, ${ }^{1}$ Karima Kahlouche, ${ }^{1,2,3}$ Alexandre Barras, ${ }^{1}$ Nao Yamakawa, ${ }^{4}$ Julie Bouckaert, ${ }^{4}$ Tijani Gharbi, ${ }^{2}$ Sabine Szunerits ${ }^{1 *}$ and Rabah Boukherroub ${ }^{1 *}$

${ }^{1}$ Univ. Lille, CNRS, Central Lille, ISEN, Univ. Valenciennes, UMR 8520, IEMN, F59000 Lille, France

${ }^{2}$ Laboratoire de Nanomédecine, imagerie et thérapeutique, EA 4662, Université de Franche-Comté, 16 Route de Gray, 25030 Besançon, France

${ }^{3}$ Centre for Development of Advanced Technologies (CDTA), Baba Hassen, Algeria

*To whom correspondence should be addressed: sabine.szunerits@univ-lille1.fr; rabah.boukherroub@univ-lille1.fr 
${ }^{4}$ Unité de Glycobiologie Structurale et Fonctionnelle (UGSF), Univ. Lille, CNRS, UMR 8576, 59655 Villeneuve d'Ascq, France

\begin{abstract}
Fast, reliable and selective detection of microorganisms is of uttermost importance in clinical analysis, but also in food and water quality monitoring. In this study, we report on the construction of an immunosensor for sensitive and selective electrochemical detection of uropathogenic Escherichia coli (E. coli) UTI89 bacteria in aqueous and serum samples. We took benefit of electrophoretic deposition (EPD) to prepare, in a simple, controllable and cost effective way, gold electrodes modified with thin active layers of reduced graphene oxide/polyethylenimine (rGO/PEI). While rGO exhibits high surface area and favourable electrochemical properties, the presence of abundant $-\mathrm{NH}_{2}$ groups on PEI offers a plethora of opportunities for the sensor's surface functionalization. To achieve selectivity of detection, the electrode surface was covalently modified with anti-fimbrial $E$. coli antibodies via amide bond formation. To minimize non-specific adsorption, the immunosensor was additionally modified with pyrene-polyethyleneglycol (pyrene-PEG) moieties prior to antibody immobilization. The detection of $E$. coli was based on the restriction of electron transfer of a redox mediator, in our case potassium ferrocyanide, to the rGO/PEI modified electrical transducer due to the formation of an immune complex. The developed immunosensor displayed a sigmoidal shape with a linear range from to $1 \times 10^{1-} 1 \times 10^{4} \mathrm{cfu} \mathrm{mL} \mathrm{m}^{-1}\left(\mathrm{R}^{2}=0.995\right)$ according to $i(\mu \mathrm{A})=-16.66-20.5 \times \log [$ E.coli $](\mathrm{cfu}$
\end{abstract}


$\mathrm{mL}^{-1}$ ) and a detection limit of $10 \mathrm{cfu} \mathrm{mL}^{-1}$. Additionally, the sensor performed well both in aqueous and urine media, which is essential for its potential use for clinical diagnosis of pathogenic diseases. Selectivity studies showed that the immunosensor was able to discriminate between E. coli UTI89 wild-type strain and UTI89 $\Delta$ fim, without fim operon.

Keywords: Electrophoretic deposition; reduced graphene oxide; polyethyleneimine; anti-fimbrial E. coli antibodies; E. coli UTI89 bacteria; electrochemical sensing.

\section{Introduction}

Urinary tract infections (UTIs) represent the most common bacterial infectious diseases for humans, and Escherichia coli (E. coli) are the most predominant pathogens responsible for 30-50\% of hospital acquired and $80-90 \%$ of communityacquired UTIs [1]. Pathogenic E. coli bacteria produce virulence factors, able to infect and cause disease to the host tissues. Thus, it is of high importance to detect these microorganisms at a very low level and be able to discriminate between different bacterial strains. The common techniques for bacteria identification and detection rely on conventional culturing techniques [2]. However, these techniques are timeconsuming, very elaborate and necessitate microbiology laboratory to be completed. Also these standard methods take up to a full day to rule out a negative sample, and the analysis may require up to several days to confirm a positive result. As such, these techniques are not suitable for on-site monitoring. Therefore, there is continuously a huge demand for the implementation of rapid, reliable, specific and highly sensitive detection of bacteria at a low cost. In this context, biosensors occupy a central position to achieve these goals [3-5].

The last decade has witnessed an emergence of a plethora of 2D materials [6]. Particularly, graphene has attracted a big deal of interest for its outstanding properties 
such as good conductivity, high surface area, ease of production and functionalization using different routes,... [6]. These properties have been exploited in various applied fields and particularly for sensing small organic molecules, metal ions and biological species $[7,8]$.

Detection of pathogens with graphene based sensors represents thus an appealing technology. A vast amount of work has been performed using graphene-based field effect transistors (GFETs) [9-11]. Huang et al. investigated CVD graphene derivatized with anti-E. coli antibodies for sensing $E$. coli bacteria with a detection limit of $10 \mathrm{cfu} \mathrm{mL}^{-1}$ [11]. Chang et al. described a GFET comprising anti-E. coli modified thermally-reduced graphene oxide sheets (rGO) semiconducting channels for the selective and sensitive detection of E. coli O157:H7 [9]. A low detection limit of $10 \mathrm{cfu} \mathrm{mL}^{-1}$ was achieved under optimized conditions. Chen et al. utilized holey rGO chemically functionalized with an antimicrobial peptide, Magainin I, as the transducer element in a GFET for E. coli O157:H7 detection [10]. The device exhibited a good selectivity and a detection limit of $803 \mathrm{cfu} \mathrm{mL^{-1 }}$.

Electrochemical detection of pathogens based on impedimetric [12-17] approaches is another particular appealing technique for fast and selective detection of pathogens, due to its low cost, simplicity of operation, and the possibility of miniaturization and portability [18]. Voltammetric and amperometric-based immunoassays for pathogen sensing are in addition popular label-free approaches [19-22]. Ahmed et al. reported on an antibody-based immunosensor for the specific detection of $S$. pyogenes pathogenic bacteria in human saliva with a linear response of $10^{2}$ to $10^{5}$ cells [19]. The integration of graphene nanostructures has proven to be advantageous in enhancing sensitivity of electrochemical sensors. Consequently, some recent works focused on the use of graphene composite electrodes for the construction of electrochemical immunosensors for the detection of pathogenic bacteria [23].

In a recent work by our group, we have studied the influence of the chemical composition and charge of graphene-gold interfaces on the adhesion strength of different E. coli strains through surface plasmon resonance (SPR) measurements [24]. Our results revealed that uropathogenic E. coli UTI89 interacts strongly with polyethyleneimine (PEI) modified graphene surfaces through electrostatic interactions. Given that these interactions are not specific, in this study, we propose a new strategy for rapid and specific detection of uropathogenic E. coli UTI89 in aqueous and serum samples using an electrochemical read out. The sensitive and 
selective detection of $E$. coli UTI89 is achieved through chemical functionalization of the $-\mathrm{NH}_{2}$ groups of PEI modified reduced graphene oxide $(\mathrm{rGO})$ electrodes with antifimbiral E. coli antibodies along with poly(ethylene glycol) (PEG) modified pyrene units to inhibit non-specific adsorption of $E$. coli bacteria onto the sensor surface. The change in the peak current of potassium ferrocyanide redox probe using differential pulse voltammetry (DPV) was used for the quantitative analysis of E. coli UTI89 contaminated solutions. It relies on the fact that the formation of an immunocomplex between anti-fimbiral E. coli antibodies and E. coli UTI89 induces a restriction of electron transfer of potassium ferrocyanide to the electrical transducer, which scales linearly with E. coli UTI89 concentration. The designed pathogen chip can specifically detect E. coli UTI89 down to $10 \mathrm{cfu} \mathrm{mL}^{-1}$ in a highly specific manner even in blood and urine samples.

\section{Experimental section}

\subsection{Materials}

Polyethyleneimine (PEI, Mw 25,000), 1-ethyl-3[3-dimethylaminopropyl] carbodiimide hydrochloride (EDC. $\mathrm{HCl}$ ), $N$-hydroxysuccinimide (NHS), phosphate buffer (PBS, $10 \mathrm{mM}, \quad \mathrm{pH}$ 7.4), potassium ferrocyanide $\left(\left[\mathrm{K}_{4} \mathrm{Fe}(\mathrm{CN})_{6}\right]\right)$, hexaammineruthenium(III) chloride $\left(\left[\mathrm{Ru}\left(\mathrm{NH}_{3}\right)_{6}\right] \mathrm{Cl}_{3}\right), 1$-pyrenecarboxylic acid $(97 \%$, Pyr-COOH), $N, N^{\prime}$-disuccinimidyl carbonate ( $\geq 95.0 \%$, DSC), dichloromethane $\left(\mathrm{CH}_{2} \mathrm{Cl}_{2}\right), \quad$ triethylamine $(\geq 99.5 \%, \quad$ TEA), O-(2-aminoethyl)-O'-(2methylethyl)heptaethylene glycol $\left(\geq 90 \%, \mathrm{NH}_{2}-\mathrm{PEG}_{8}-\mathrm{N}_{3}\right)$ were obtained from SigmaAldrich (France).

Graphene oxide (GO) powder was obtained from Graphenea, Spain.

Serum and urine samples were kindly provided by the Centre Hospitalier Universitaire of Lille.

2.2. Formation of anti-fimbrial $E$. coli modified pyrene-PEG coated rGO/PEI modified electrodes (PEG/rGO/PEI-anti-fimbrial)

2.2.1 Electrophoretic deposition of reduced graphene oxide/polyethylenimine (rGO/PEI) on Au electrode

Graphene oxide/polyethyleneimine (GO/PEI) aqueous dispersion was obtained by stirring for $48 \mathrm{~h}$ at room temperature a mixture of GO $\left(1 \mathrm{mg} \mathrm{mL}^{-1}\right)$ and PEI $(1 \mathrm{mg} \mathrm{mL}$ 
$\left.{ }^{1}\right)$ at a volume ratio of $1 / 1$. The Au thin film electrode was functionalized through electrophoretic deposition (EPD) of rGO/PEI using GO/PEI aqueous dispersion in a two-electrode cell by applying a DC voltage $(15 \mathrm{~V})$ for $4 \mathrm{~min}$. The Au electrode acts as the cathode and a Pt foil $\left(1 \times 2 \mathrm{~cm}^{2}\right)$ as the anode. After deposition, the interface was rinsed copiously with Milli-Q water and dried in air.

\subsubsection{Functionalization of rGO/PEI interface with pyrene-PEG (PEG/rGO/PEI)} The Au/rGO/PEI interface was immersed in $5 \mathrm{mM}$ pyrene-PEG (see SI for synthesis) aqueous solution at room temperature for $1 \mathrm{~h}$. The resulting surface was extensively rinsed with Milli-Q water and dried under a stream of nitrogen.

\subsubsection{Covalent immobilization of anti-fimbrial $E$. coli antibodies onto} PEG/rGO/PEI electrode (PEG/rGO/PEI-anti-fimbrial)

Covalent linking of rabbit anti-fimbrial antibody onto $\mathrm{rGO} / \mathrm{PEI}$ functionalized with pyrene-PEG was achieved through chemical coupling of the $-\mathrm{NH}_{2}$ groups of PEI with the $-\mathrm{COOH}$ functions of anti-fimbrial $E$. coli antibodies using EDC/NHS as crosslinking agents. Briefly, the PEG/rGO/PEI coated gold interface was incubated in an aqueous solution of anti-fimbrial E. coli antibody solution $\left(10 \mathrm{ng} \mathrm{mL}^{-1}\right), \mathrm{EDC} \cdot \mathrm{HCl}$ $(25 \mathrm{mM})$ and NHS $(25 \mathrm{mM})$ at $4{ }^{\circ} \mathrm{C}$ for $2 \mathrm{~h}$ under agitation. The resulting surface was washed copiously with PBS to remove excess antibodies and unreacted reagents. The functionalized surface was then stored in PBS buffer at $4{ }^{\circ} \mathrm{C}$ before use.

\subsection{Characterization}

\section{Zeta-potential measurements}

The surface properties of the prepared samples were assessed by zeta-potential measurements using a Zeta-sizer Nano-ZS (Malvern Instruments Inc. Worcestershire, UK). The measurements were performed in Milli-Q water ( $\mathrm{pH}$ 7.0) at a sample concentration of $25 \mu \mathrm{g} \mathrm{mL}^{-1}$.

Scanning Electron Microscopy (SEM)

The morphology of the surface was examined by an electron microscope ULTRA 55 (Zeiss, France) equipped with a thermal field emission emitter and a high efficiency In-lens SE detector. 
SEM images of pathogens were recorded using a Zeiss Compat Merlin instrument at 2 $\mathrm{kV}$ under high vacuum. The biological samples were fixed with $1 \%$ glutaraldehyde solution for $30 \mathrm{~min}$ at room temperature in the dark and then coated with a $5 \mathrm{~nm}$-thick platinum film.

Optical profilometry

An optical profilometer (ZygoNewView 6000 Optical Proilometer with MetroPro software) with $1 \mathrm{~nm}$ height resolution was used for thickness measurements.

\section{Electrochemical measurements}

The electrochemical properties of the developed electrodes were assessed by cyclic voltammetry $(\mathrm{CV})$ and differential pulse voltammetry (DPV) using an Autolab potentiostat 30 (Eco-Chemie, Utrech, The Netherlands). A conventional threeelectrodes system consisting of a working electrode (Au film), a reference electrode (silver wire), and a counter electrode (platinum mesh) was used. The following optimized conditions (modulation time: $0.05 \mathrm{~s}$; interval time: $0.5 \mathrm{~s}$; step potential: 5 $\mathrm{mV}$; modulation amplitude: $50 \mathrm{mV}$ ) were used to record differential pulse voltammograms.

2.4 Bacterial culture, incubation and detection based on anti-fimbrial $E$. coli antibodies modified PEG/rGO/PEI interface

Three bacterial strains are used in this study, including E. coli UTI89 (wild-type strain), E. coli UTI89 $\Delta$ fim (without fim operon) and $S$. aureus. A single E. coli or $S$. aureus colony from LB/BHI agar plate complemented with the appropriate antibiotics was inoculated overnight in LB/BHI medium at $37{ }^{\circ} \mathrm{C}$ with moderate shaking. The pre-culture was diluted 50-fold and kept under moderate shaking for another 3-4 h, until the $\mathrm{OD}_{600 \mathrm{~nm}}$ had reached 0.6 - 1 . The bacteria were re-suspended in sterile Milli$\mathrm{Q}$ water and adjusted to the required concentration $\left(1 \times 10^{1}-1 \times 10^{8} \mathrm{cfu} \mathrm{mL}^{-1}\right)$.

A series of bacteria cell concentrations ranging from $1 \times 10^{1}$ to $1 \times 10^{8} \mathrm{cfu} \mathrm{mL}^{-1}$ in 100 $\mu \mathrm{L}$ volume were incubated on anti-fimbrial $E$. coli antibodies functionalized PEG/rGO/PEI electrode for $30 \mathrm{~min}$ to achieve bacterial cells immobilization. After incubation, the functionalized electrode was copiously rinsed with Milli-Q water to remove excess planktonic cells and then kept in PBS buffer or growth medium at $4{ }^{\circ} \mathrm{C}$ for further analysis. Finally, the electrochemical response of the $10 \mathrm{mM}\left[\mathrm{Fe}(\mathrm{CN})_{6}\right]^{3-14-}$ probe in $0.1 \mathrm{M} \mathrm{KCl}$ was recorded using DPV. 


\section{Results and Discussion}

\subsection{Formation of reduced graphene oxide/polyethylenimine (rGO/PEI) modified}

interfaces

Figur 1A outlines the strategy employed for the preparation of functionalized electrodes for specific detection of E. coli UTI89 by electrochemical means. It is based on the functionalization of a gold $(\mathrm{Au})$ electrode by electrophoretic deposition of rGO/PEI, followed by non-covalent modification with pyrene-PEG (see SI for synthesis) and covalent linking of E. coli UTI89 anti-fimbrial antibodies to the amine groups of PEI. We opted for the electrophoretic depositon (EPD) concept, as anodic EPD of rGO using GO as a starting material was reported to result in highly stable interfaces that can be produced in a cost-effective manner and good reproducibility. As such, EPD is well adapted for the functionalization of different electrode surfaces for designing sensing platforms [25]. GO aqueous solutions exhibit a negative $(\zeta=-$ $41.3 \pm 0.8 \mathrm{mV}$ ) zeta potential and the GO platelets migrate towards the anode upon application of a DC voltage [26]. For a more complete reduction of GO to rGO, cathodic EPD depositon and a matrix with positive zeta potential is required. This can be achieved by charging of GO with a cationic polymer with repeated amine groups such as polyethyleneimine (PEI). A 1/1 mixture of GO and PEI results in GO/PEI nanosheets with $\zeta=+36.4 \pm 1.3 \mathrm{mV}$, being well adapted for cathodic EPD.

Figure 1B shows the morphology of a thin $\mathrm{Au}$ electrode before and after electrophoretic coating with $\mathrm{rGO} / \mathrm{PEI}$. Upon the application of $+15 \mathrm{~V}_{\mathrm{DC}}$ for $4 \mathrm{~min}$, the Au electrode is coated with a homogeneous film of rGO/PEI nanoplatelets of about 4 $\mathrm{nm}$ in thickness, as determined by profilometry measurements.

Figure 1C exhibits the differential pulse votammograms of the thin film $\mathrm{Au}$ electrode before and after coating with rGO/PEI through electrophoretic deposition using $\left[\mathrm{Fe}(\mathrm{CN})_{6}\right]^{4-}$ as the redox probe. As compared to bare Au electrode, functionalization with a thin rGO/PEI film resulted in a significant increase of the redox current. The enhanced current of the Au electrode modified with rGO/PEI thin film correlates most likely with the good electronic properties of rGO/PEI, increased surface area and favourable electrostatic interactions between the negatively charged redox probe and the positively charged rGO/PEI interface. Indeed, using a positively charged redox probe led to a small increase of the redox current for the rGO/PEI 
interface when compared to bare Au electrode (see SI, Figure 1A).

(A)

1. Electrophoretic deposition

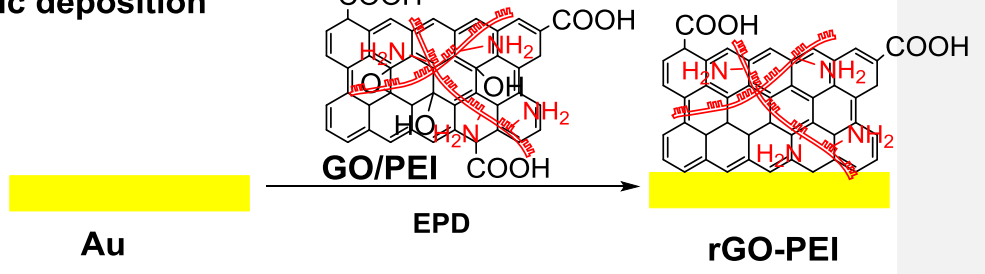

2. Modification with anti-fimbrial antibodies and pyrene-PEG

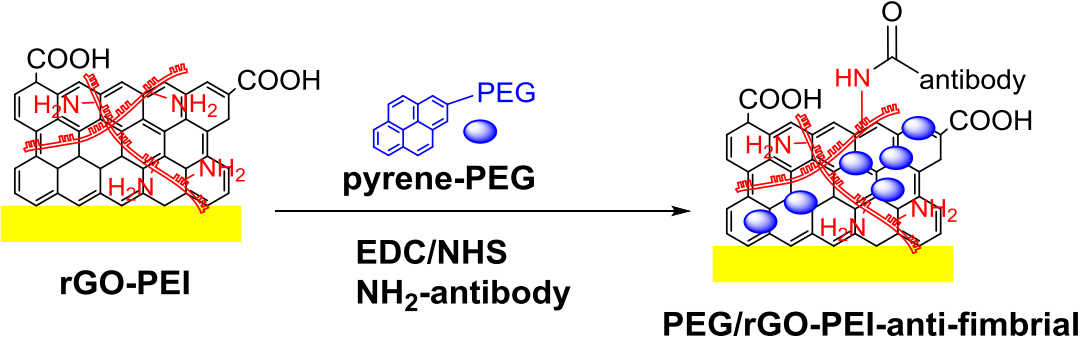

(B)

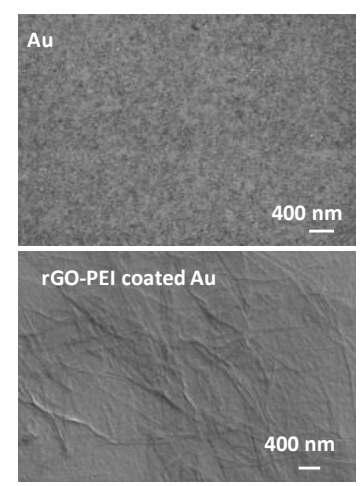

(C)

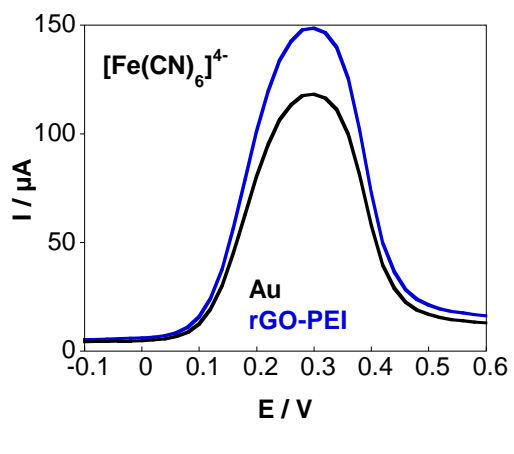

Figure 1: (A) Different steps employed for the construction of the immunosensor for the selective electrochemical detection of E. coli UTI89; (B) Scanning electron microscopy (SEM) micrographs of Au electrodes before and after electrophoretic coating with rGO/PEI nanoflakes upon application of $15 \mathrm{~V}_{\mathrm{DC}}$ for $4 \mathrm{~min}$; (C) 
Differential pulse voltammograms of $\mathrm{Au}$ (black) and Au coated with rGO/PEI (blue) recorded in $\left[\mathrm{Fe}(\mathrm{CN})_{6}\right]^{4-}(10 \mathrm{mM}) / \mathrm{KCl}(0.1 \mathrm{M})$.

To determine whether rGO/PEI coated Au electrodes are adaptable for bacteria sensing, the interfaces were first immersed into E. coli solutions. Figure $2 \mathrm{~A}$ shows the change in the redox current of the rGO/PEI coated Au interface using $\left[\mathrm{Fe}(\mathrm{CN})_{6}\right]^{4-}$ as the redox probe upon incubation for $30 \mathrm{~min}$ in E. coli UTI89 solution of different concentrations. After an insignificant increase in the peak current for E. coli solution of $10^{2} \mathrm{cfu} \mathrm{mL}^{-1}$, a small but steady decrease in the redox current is observed upon increasing the $E$. coli concentration. The interfaces proved however to be not highly specific towards E. coli UTI89, especially at low concentrations, where a comparable change in electrochemical signature is observed upon incubation with E. coli UTI89 $\Delta$ Fim, a modified E. coli UTI89 strain deprived bacteria fimbrials (Figure 2B). SEM images of an rGO/PEI coated Au interface incubated with E. coli UTI89 for $30 \mathrm{~min}$ confirmed E. coli UTI89 adsorption on the interface (Figure 2C).

(A)

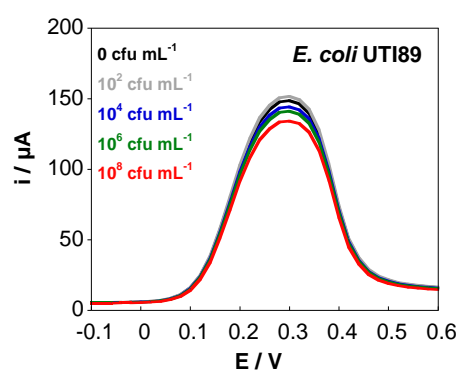

(B)

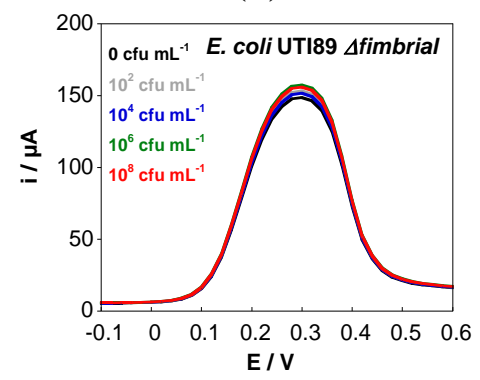

(C)

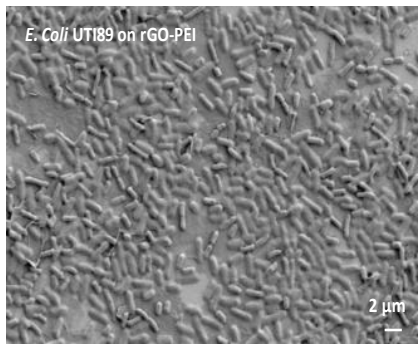


Figure 2: Differential pulse voltammograms recorded in $\left[\mathrm{Fe}(\mathrm{CN})_{6}\right]^{4-}(10 \mathrm{mM}) / \mathrm{KCl}$ $(0.1 \mathrm{M})$ on $\mathrm{rGO} / \mathrm{PEI}$ coated Au electrodes before (black) and after incubation for 30 min with E. coli UTI89 (A) and E. coli UTI89 $\Delta$ fimbrial (B) solutions of different concentrations; (C) SEM image of rGO/PEI coated Au electrode incubated with $E$. coli UTI89 $\left(10^{8} \mathrm{cfu} \mathrm{mL}^{-1}\right)$ for $30 \mathrm{~min}$.

\subsection{Formation of anti-fouling anti-fimbrial $E$. coli antibodies modified rGO/PEI}

\section{Au electrodes}

The selective detection of bacteria was achieved through covalent functionalization of the $\mathrm{Au} / \mathrm{rGO} / \mathrm{PEI}$ interface with antibodies against the major pilin protein FimA of the E. coli UTI89 type-1 fimbriae using the classical NHS/EDC coupling chemistry (Fig. 1A). Indeed, surface plasmon resonance (SPR) investigations showed specific and concentration-dependent interactions of the IgG polyclonal antibodies with purified type-1 fimbriae immobilized onto a CM5 sensor chip, using the standard EDC/NHS procedure (see SI, Figure S2). The best fit could be obtained using a Langmuir 1:1 binding model, with a global $\mathrm{K}_{\mathrm{d}}$ value of $6 \pm 4 \mu \mathrm{M}$. The same surface functionalization strategy was employed for the electrochemical sensing interface using EDC/NHS chemistry, resulting in amide bond formation between the free $-\mathrm{NH}_{2}$ functions present on the $\mathrm{rGO} / \mathrm{PEI}$ matrix and the available $\mathrm{COOH}$ groups of the antibody (Figure 1A). To minimize anti-fouling issues, prior to antibody immobilization, the rGO/PEI coated $\mathrm{Au}$ electrode was immersed into pyrene-PEG to block free rGO sites. In fact, this has proved to be more efficient when compared to post-functionalization of antibody modified rGO/PEI interfaces with pyrene-PEG; this is most likely due to the restriction of $\pi-\pi$ stacking and H-bonding interactions of pyrene moieties with rGO by the anti-fimbrial E. coli antibodies immobilized on the rGO/PEI surface.

\subsection{Electrochemical detection}

The electrochemical response of the anti-fimbrial E. coli antibody modified interfaces was further investigated. While pyrene-PEG does not influence the electron transfer, its presence shows excellent anti-fouling properties (Figure 3A). Linking antibodies against the FimA major pilin of E. coli UTI89 type-1 fimbriae to the 
interface results in a partial blocking of the electron transfer of $\left[\mathrm{Fe}(\mathrm{CN})_{6}\right]^{4-}$ seen in the decrease of the redox current (Figure 3B).

SEM imaging of pyrene-PEG modified rGO/PEI after immersion in E. coli UTI89 at a high concentration of $1 \times 10^{8} \mathrm{cfu} \mathrm{mL}^{-1}$ for $2 \mathrm{~h}$ indicates clearly the absence of pathogens on the surface and the good anti-fouling properties of pyrene-PEG modified electrodes (Figure 3C). This image contrasts that obtained when antifimbrial were immobilized on the surface (Figure 3D).

(A)

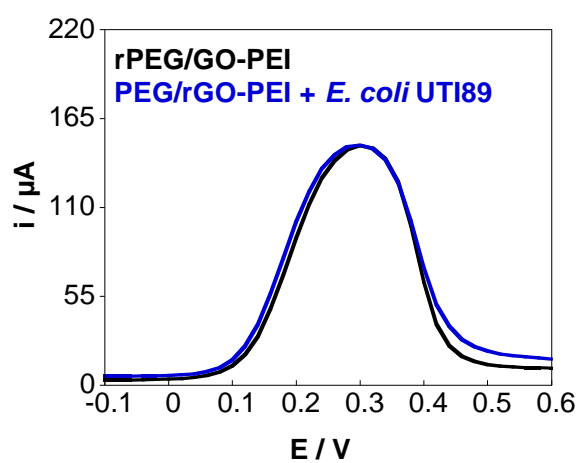

(C)

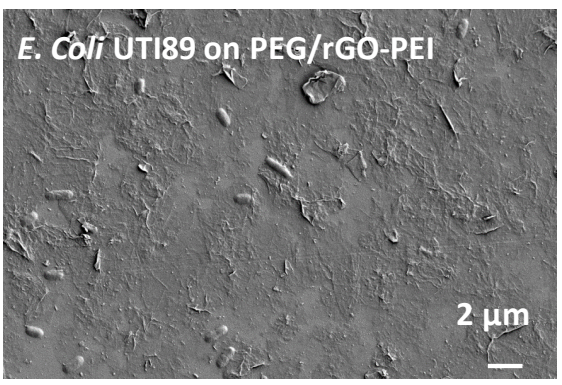

(B)

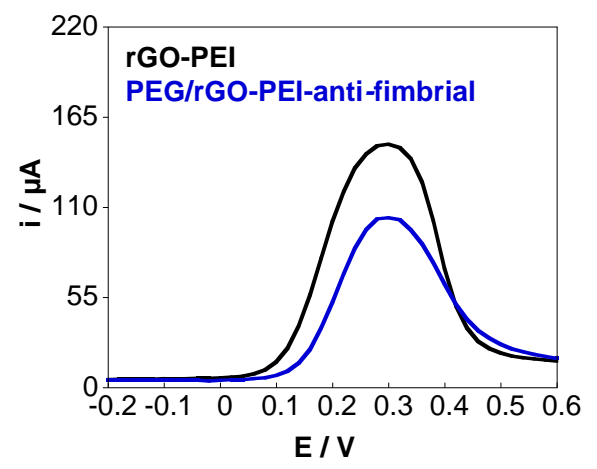

Figure 3: (A) DPVs of PEG/rGO/PEI modified Au electrodes before and after incubation for $2 \mathrm{~h}$ in E. coli UTI89 $\left(10^{8} \mathrm{cfu} \mathrm{mL}^{-1}\right)$ solution containing $\left[\mathrm{Fe}(\mathrm{CN})_{6}\right]^{4-}$ $(10 \mathrm{mM}) / \mathrm{KCl}(0.1 \mathrm{M})$; (B) DPVs of PEG/rGO/PEI-anti-fimbrial modified $\mathrm{Au}$ electrodes before and after incubation for $2 \mathrm{~h}$ in E. coli UTI89 $\left(10^{8} \mathrm{cfu} \mathrm{mL}^{-1}\right)$ solution 
containing $\left[\mathrm{Fe}(\mathrm{CN})_{6}\right]^{4-}(10 \mathrm{mM}) / \mathrm{KCl}(0.1 \mathrm{M})$; SEM images of PEG/rGO/PEI $(\mathbf{C})$ and PEG/rGO/PEI-anti-fimbrial (D) modified Au electrodes after $2 \mathrm{~h}$ of incubation with E. coli UTI89 wt $10^{8} \mathrm{cfu} \mathrm{mL}^{-1}$.

The sensitivity of the PEG/rGO/PEG-anti-fimbrial electrode towards the selective detection of E. coli UTI89 in aqueous solution was performed in a wide range of bacteria concentrations. Figure 4A depicts the change of the DPV peak current of $\left[\mathrm{Fe}(\mathrm{CN})_{6}\right]^{4-}$ redox probe upon incubation of the electrode for $30 \mathrm{~min}$ with $E$. coli UTI89. In absence of bacteria (control), the current value was $144 \pm 3 \mu \mathrm{A}\left(\mathrm{I}_{0}\right)$. Once UTI89 bacteria (100 $\mathrm{cfu} \mathrm{mL}^{-1}$ ) was added, the electrochemical response of the system was altered due to electron transfer restriction of $\left[\mathrm{Fe}(\mathrm{CN})_{6}\right]^{4-}$ to the electrical interface and the current decreased to $120 \pm 3 \mu \mathrm{A}\left(\mathrm{I}_{\mathrm{c}}\right)$ and even further with an increasing concentration of UTI89 cells in solution. To demonstrate the sensor's performance to transduce the biorecognition reaction between the antibody and the FimA carrying pathogen into measureable signals, the change in current as a function of pathogen concentration was plotted. As seen from the calibration curve in Figure 4B, where the change in the peak current $\mathrm{I}_{O}-\mathrm{I}_{\mathrm{c}}$ vs. $\log \left[\right.$ E. coli UTI89] is plotted, with $\mathrm{I}_{\mathrm{O}}$ being the initial current in the absence of pathogens, a linear range from to $1 \times 10^{1-} 1 \times 10^{4} \mathrm{cfu} \mathrm{mL}^{-}$ ${ }^{1}\left(\mathrm{R}^{2}=0.995\right)$ according to $i(\mu \mathrm{A})=-16.66-20.5 \times \log [$ E.coli $]\left(\mathrm{cfu} \mathrm{mL}^{-1}\right)$ is obtained. The system displays a detection limit for UTI89 below $10 \mathrm{cfu} \mathrm{mL}^{-1}$ from five blank signals (95\% confidence level).

(A)

(B) 

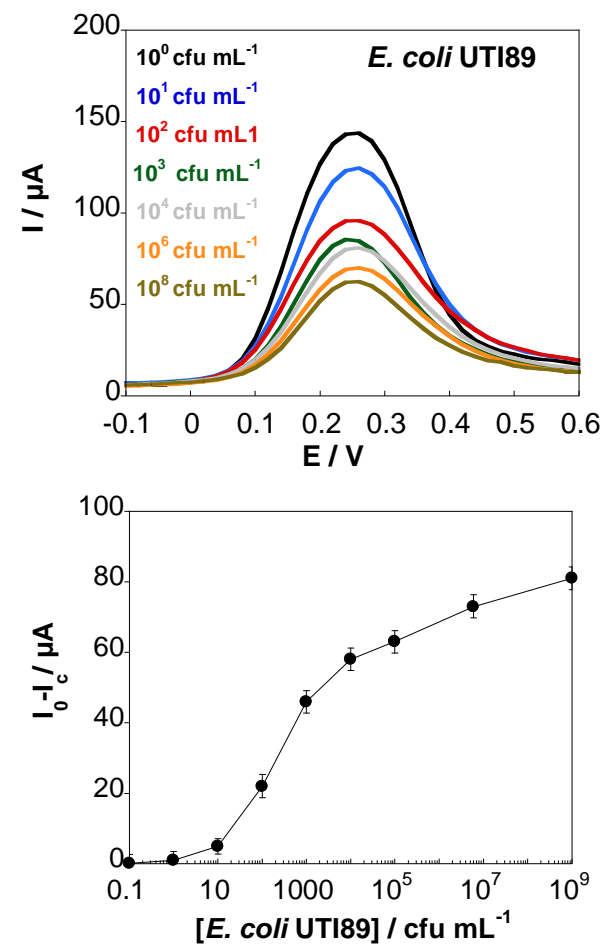

Figure 4: (A) Change in oxidative current of DPVs in $\left[\mathrm{Fe}(\mathrm{CN})_{6}\right]^{4-}(10 \mathrm{mM}) / \mathrm{KCl}(0.1$ M) upon incubation for $30 \mathrm{~min}$ in aqueous solutions of E. coli UTI89 of different concentrations $\left(10^{1}-10^{8} \mathrm{cfu} \mathrm{mL}^{-1}\right)$ using the developed PEG/rGO-PEI-anti-fimbrial modified Au electrodes; (B) Respective calibration curve for E. coli UTI89 solutions.

Table 1 compares the electroanalytical performance of our sensor to other pathogen electrical or electrochemical sensing platforms. The performance of the developed sensor is comparable or slightly lower to those described in the literature. However, the linear range recorded for our sensor is quite large as compared to that reported for other systems with the benefit of the present sensor of being easy to implement and versatile. In fact, the PEI contains plenty of $-\mathrm{NH}_{2}$ groups that can be easily coupled to various functional groups for designing different sensing platforms. Additionally, the electrophoretic deposition method used for the functionalization scheme is a fairly rapid and a low cost process employed for a broad range of industrial processes.

Table 1: Selected examples of E. coli immunosensors reported in the literature. 


\begin{tabular}{|c|c|c|c|c|c|}
\hline Method & Interface & pathogen & $\begin{array}{c}\text { LOD } \\
\text { cfu mL } \mathrm{mL}^{-1}\end{array}$ & $\begin{array}{c}\text { Linear } \\
\text { range }\end{array}$ & Ref. \\
\hline EIS & $\begin{array}{l}\mathrm{Ec}_{\mathrm{AB}} / \mathrm{rGO}-\mathrm{Cys} \mathrm{Cu} / \\
\mathrm{Au} \text { electrode/ }\end{array}$ & $\begin{array}{c}\text { E.coli } \\
\text { O157:H7 }\end{array}$ & 3.8 & $10^{1}-10^{8}$ & \\
\hline EIS & $\begin{array}{l}\text { Anti- } E \text {. coli } \\
\text { antibodies/ SAM/ } \\
\text { Au electrode }\end{array}$ & E. coli & 10 & $10-10^{3}$ & \\
\hline EIS & $\begin{array}{l}\text { Anti- } E \text {. coli } \\
\text { antibodies/IDA } \\
\text { microeectrode }\end{array}$ & $\begin{array}{c}\text { E.coli } \\
\text { O157:H7 }\end{array}$ & $6 \times 10^{6}$ & $\begin{array}{c}4.36 \times 10^{5} \\
4.36 \times 10^{8}\end{array}$ & \\
\hline EIS & $\begin{array}{l}\text { Anti- E. coli } \\
\text { antibodies/ SAM/ } \\
\text { Au electrode }\end{array}$ & E. coli & $10^{3}$ & $3 \times 10^{3}-3 \times 10^{7}$ & \\
\hline EIS & $\begin{array}{l}\text { Anti- E. coli } \\
\text { antibodies/ } \\
\text { Glu/PANI/Au } \\
\text { electrode }\end{array}$ & $\begin{array}{c}\text { E.coli } \\
\text { O157:H7 }\end{array}$ & 100 & $10^{2}-10^{7}$ & \\
\hline EIS & $\begin{array}{l}\text { thiolated } \\
\text { antibodies/Au } \\
\text { SPEs }\end{array}$ & E. coli & 3.3 & $5-10^{8}$ & \\
\hline Amperometric & $\begin{array}{l}\text { Anti- E. coli } \\
\text { antibodies / Au } \\
\text { NPs / FeDC } \\
\text { modified SPCEs }\end{array}$ & $\begin{array}{c}\text { E.coli } \\
\text { O157:H7 }\end{array}$ & 600 & $10^{2}-10^{7}$ & \\
\hline Capacitance & $\begin{array}{l}\text { Graphene }+ \\
\text { pyrene-maleimide } \\
\text { +anti-E. coli } \\
\text { antibodies }\end{array}$ & $\begin{array}{c}\text { E.coli } \\
\text { O157:H7 }\end{array}$ & $10-100$ & $10-10^{7}$ & [25] \\
\hline GFET & $\begin{array}{l}\text { CVD graphene }+ \\
\text { anti- } E \text {. coli } \\
\text { antibodies }\end{array}$ & E. coli & 10 & $10-10^{4}$ & [9] \\
\hline GFET & $\begin{array}{l}\text { rGO + anti-E. coli } \\
\text { antibodies }\end{array}$ & $\begin{array}{c}\text { E. coli } \\
\text { O157:H7 }\end{array}$ & 10 & $10-10^{3}$ & [7] \\
\hline GFET & $\begin{array}{l}\text { holey reduced } \\
\text { graphene oxide } \\
\text { functionalized + } \\
\text { antimicrobial } \\
\text { peptide }\end{array}$ & E. coli & 803 & - & [8] \\
\hline Potentiometric & rGO+aptamer & S. aureus & 1 & $10-10^{3}$ & [26] \\
\hline DPV & $\begin{array}{l}\text { rGO-PEI+anti- } \\
\text { fimbrial antibody }\end{array}$ & $\begin{array}{l}\text { E. coli } \\
\text { UTI89 }\end{array}$ & 100 & $10^{1}-10^{7}$ & $\begin{array}{l}\text { This } \\
\text { work }\end{array}$ \\
\hline
\end{tabular}

Comment [RJ1]: Pandey, Chandra Mouli, et al. "Highly sensitive electrochemical immunosensor based on graphene-wrapped copper oxidecysteine hierarchical structure for detection of pathogenic

bacteria." Sensors and Actuators B. Chemical 238 (2017): 1060-1069.

Comment [RJ2]: Maalouf, Rita, et al. "Label-free detection of bacteria by electrochemical impedance spectroscopy: comparison to surface plasmon resonance." Analytical chemistry 79.13 (2007): 4879-4886.

Comment [RJ3]: Yang, Liju, Yanbin $\mathrm{Li}$, and Gisela F. Erf. "Interdigitated Array Microelectrode-Based Electrochemical Impedance

Immunosensor for Detection of

Escherichia c oli O157: H7." Analytical chemistry 76.4 (2004): 1107-1113.

\section{Comment [RJ4]: Geng, Ping, et al.}

"Self-assembled monolayers-based immunosensor for detection of

Escherichia coli using electrochemical impedance

spectroscopy." Electrochimica Acta53.14 (2008): 4663-4668.

Comment [RJ5]: Chowdhury, Ankan

Dutta, et al. "Label free polyaniline based impedimetric biosensor for detection of E. coli O157: H7

Bacteria." Sensors and Actuators B. Chemical 171 (2012): 916-923.

Comment [RJ6]: Escamilla-Gómez,

Vanessa, et al. "Gold screen-printedbased impedimetric immunobiosensors for direct and sensitive Escherichia coli quantisation." Biosensors and Bioelectronics24.11 (2009): 3365-3371.

Comment [RJ7]: Lin, Yueh-Hui, et al. "Disposable amperometric immunosensing strips fabricated by $\mathrm{Au}$ nanoparticles-modified screen-printed carbon electrodes for the detection of foodborne pathogen Escherichia coli O157: H7." Biosensors and Bioelectronics 23.12 (2008): 1832Bioelectr. 1837.
It is well known that the amount of antibody linked to the surface can have important consequences onto the performance of the sensor. The amount of antibody grafted onto the PEG/rGO/PEI interface proved to be indeed of great importance for the sensing performance. Figure $\mathbf{5 A}$ depicts in the form of a bar diagram the oxidative 
current recorded upon incubation with $E$. coli UTI89 when different concentrations of anti-fimbrial $E$. coli antibodies were immobilized onto the sensor's surface. An interface modified with $10 \mathrm{ng} \mathrm{mL}^{-1}$ anti-fimbrial antibodies results indeed in an optimal sensing current to E. coli UTI89 with the largest current drop.

The specificity of this electrode architecture for the sensing of FimA carrying $E$. coli UTI89 over $\triangle$ fimA deprived E. coli is evidenced in Figure 5B, showing a far lower change of the current response compared to that of E. coli UTI89 (Figure 4A).

(A)

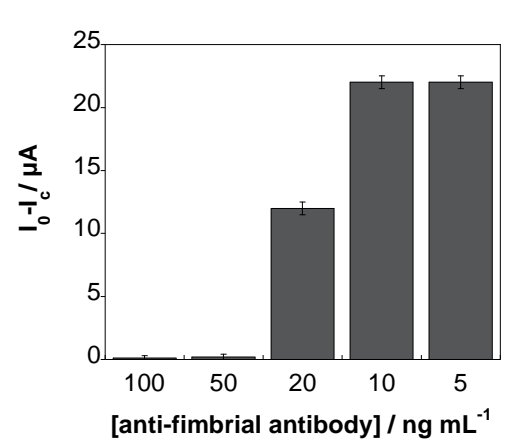

(B)

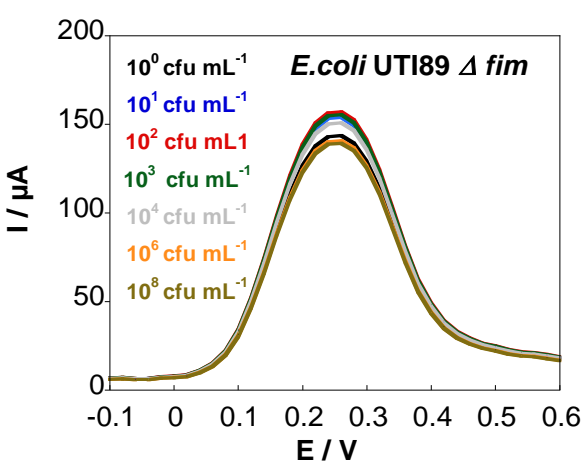

Figure 5: (A) Influence of anti-fimbrial antibody concentration on the current response of PEG/rGO/PEI-anti-fimbrial modified $\mathrm{Au}$ electrodes in $\left[\mathrm{Fe}(\mathrm{CN})_{6}\right]^{4-}$ $(10 \mathrm{mM}) / \mathrm{KCl}(0.1 \mathrm{M})$; The current was recorded upon incubation with $100 \mathrm{cfu} \mathrm{mL}^{-1}$. (B) DPV of PEG/rGO/PEI-anti-fimbrial modified $\mathrm{Au}$ electrodes measured in $\left[\mathrm{Fe}(\mathrm{CN})_{6}\right]^{4-}(10 \mathrm{mM}) / \mathrm{KCl}(0.1 \mathrm{M})$ before and after incubation for $30 \mathrm{~min}$ in aqueous solutions of E. coli UTI89 $\triangle$ fim $\left(10^{1}-10^{8} \mathrm{cfu} \mathrm{mL}^{-1}\right)$.

The reproducibility of PEG/rGO/PEI-anti-fimbrial modified gold electrodes for $E$. coli UTI89 sensing, expressed in terms of the relative standard deviation, was determined to be $2.3 \%$ at E. coli UTI89 bacteria concentration of $10^{4} \mathrm{cfu} \mathrm{mL}^{-1}(\mathrm{n}=5)$. The long-term stability of the PEG/rGO/PEI-anti-fimbrial electrode upon storage in 
PBS at $4{ }^{\circ} \mathrm{C}$ for 2 weeks was also evaluated. A loss of $2.8 \%$ in the peak current was observed at E. coli UTI89 bacteria concentration of $10^{4} \mathrm{cfu} \mathrm{mL} \mathrm{m}^{-1}$.

\subsection{Measurements in real samples}

The reliability and potential application of the developed sensor for bacteria sensing in real samples were examined. E. coli UTI levels in urine and human serum samples spiked with $E$. coli UTI at different concentrations were determined and the current response was compared to that obtained in PBS. Figure $6 \mathbf{A}$ depicts the electrochemical signal obtained from spiked serum and urine, showing the same trend as in PBS, i.e. a decrease of current with increasing E. coli UTI89 concentration. Figure 6B compares the current responses for $E$. coli UTI89 detected on the PEG/rGO/PEI-anti-fimbrial modified Au electrodes in PBS or spiked human serum and urine. The differences in detected E. coli UTI89 concentrations are within the error of the analysis technique, pointing towards the possibility to analyze real samples with the developed sensor.

(A)
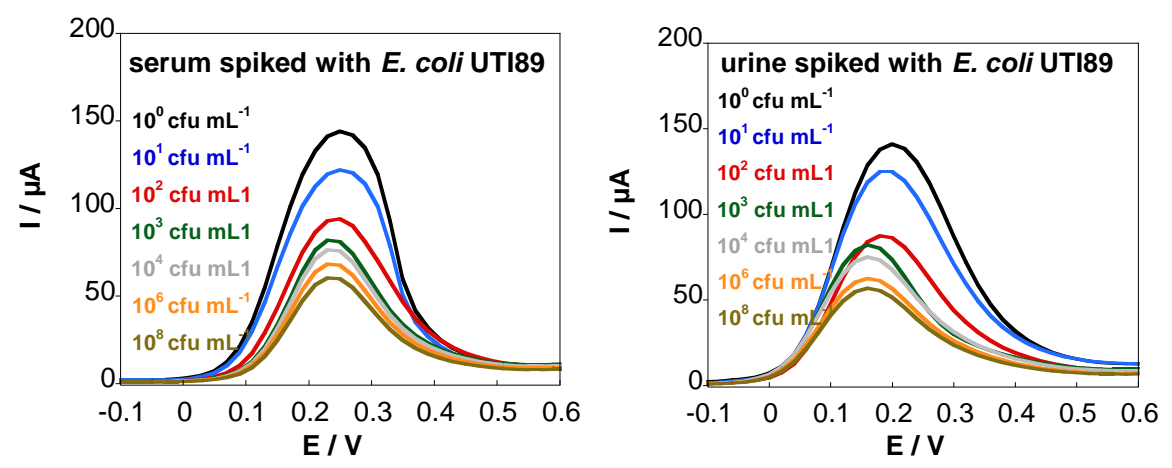

(B)

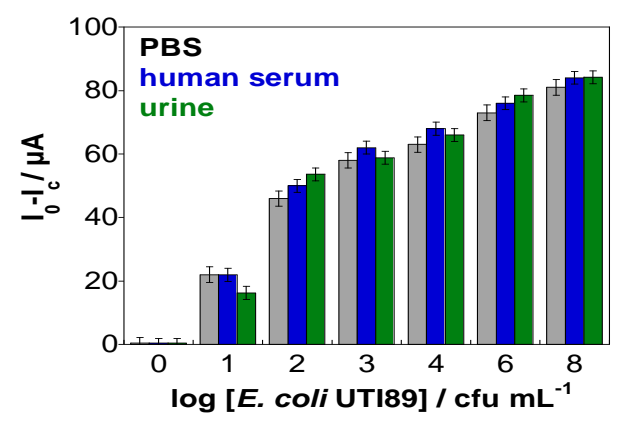

(C)

(D) 

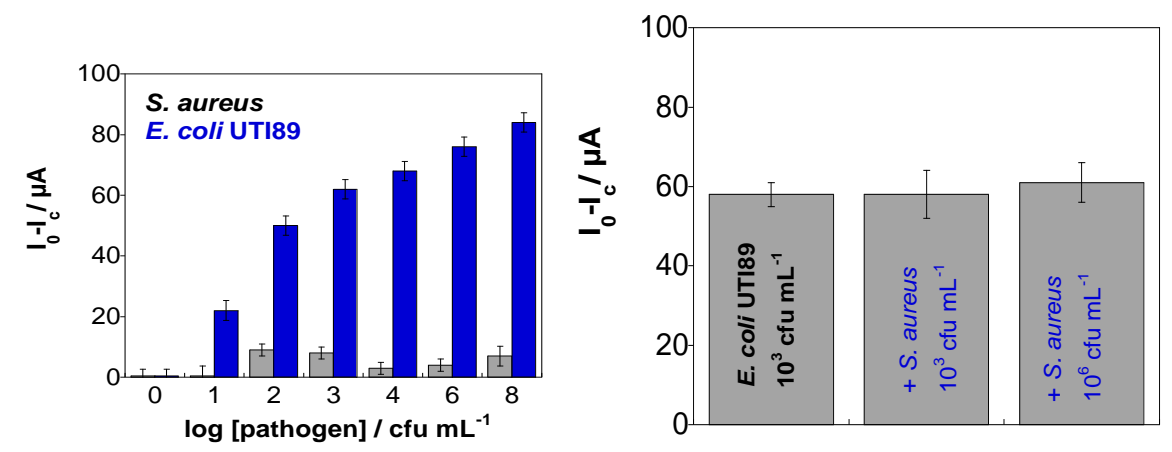

Figure 6: (A) DPV of PEG/rGO/PEI-anti-fimbrial modified gold electrodes recorded in $\left[\mathrm{Fe}(\mathrm{CN})_{6}\right]^{4-}(10 \mathrm{mM})$ before and after incubation for $30 \mathrm{~min}$ in human serum and urine samples spiked with different concentrations of E. coli UTI89 $\left(10^{1}-10^{8} \mathrm{cfu} \mathrm{mL}^{-}\right.$ $\left.{ }^{1}\right)$; (B) Comparison between the electrochemical signature of E. coli UTI89 in PBS (grey), in human serum (blue) and when analyzed in urine (green) samples; (C) Recorded oxidative current in $\left[\mathrm{Fe}(\mathrm{CN})_{6}\right]^{4-}(10 \mathrm{mM})$ in human serum spiked with different concentrations of S. aureus $\left(10^{1}-10^{8} \mathrm{cfu} \mathrm{mL}^{-1}\right)$; (D) Comparison between the electrochemical signature of human serum spiked with $10^{3} \mathrm{cfu} \mathrm{mL}^{-1}$ E. coli UTI89 and in presence of $S$. aureus at $10^{3}$ and $10^{6} \mathrm{cfu} \mathrm{mL}^{-1}$.

The specific detection of pathogenic E. coli in complex media remains a challenging task. To study if the developed electrode is indeed suitable for specific $E$. coli UTI89 sensing in serum, we first tested serum samples spiked with $S$. aureus. No change in electrochemical signal was observed even for high S. aureus concentrations, suggesting the high specificity of the anti-fimbrial modified electrode toward E. coli UTI89 (Figure 6C). The developed sensor was finally exploited to detect E. coli UTI89 in human serum samples spiked with $10^{3} \mathrm{cfu} \mathrm{mL}^{-1} E$. coli UTI89 and in addition with $S$. aureus $\left(10^{3}\right.$ and $\left.10^{6} \mathrm{cfu} \mathrm{mL}^{-1}\right)$. From Figure 6D it becomes evident that the presence of $S$. aureus is not interfering significantly with the detected current response of E. coli UTI89 on PEG/rGO/PEI-anti-fimbrial modified gold electrodes.

\section{Conclusion}

We have demonstrated the potential of polyethyleneimine modified reduced graphene oxide nanosheets electrophoretically deposited onto gold electrode for the sensitive and selective electrochemical detection of E. coli UTI89. Covalent 
functionalization of the Au electrode with anti-fimbrial $E$. coli antibodies resulted in a sensing device highly sensitive to $E$. coli UTI89. Using differential pulse volammetry measurements and $\left.\mathrm{Fe}(\mathrm{CN})_{6}\right]^{4-}$ as a redox probe, a detection limit of $10 \mathrm{cfu} \mathrm{mL}^{-1}$ was achieved. As E. coli UTI89 concentrations of $10^{4} \mathrm{cfu} \mathrm{mL}^{-1}$ are correlated to highly infected patients, the low detection limit will allow to give indication at early stages of eventual urinal infections. The interfaces proved to be also adequate for sensing in human serum and urine samples as well as in the presence of other bacteria species, making the approach of high clinical interest. Furthermore, the concept of using a rGO/PEI modified electrode for covalent modification with pathogenic antibodies is general and can be easily adapted to any other pathogen species, making the approach very versatile.

\section{Acknowledgements}

The Centre National de la Recherche Scientifique (CNRS), the University of Lille Science and technology, the Hauts-de-France region, the CPER "Photonics for Society", the Agence Nationale de la Recherche (ANR) via project ANR-12-BSV5016-01, and the EU through FLAG-ERA JTC 2015-Graphtivity and the Marie Sklodowska-Curie action (H2020-MSCA-RISE-2015, PANG-690836) are acknowledged for financial support.

\section{References}

[1] K. Ejrnaes, M. Stegger, A. Reisner, S. Ferry, T. Monsen, S.E. Holm, B. Lundgren, N. Frimodt-Moller, Characteristics of Escherichia coli causing persistence or relapse of urinary tract infections, Virulence 2 (2011) 528-537.

[2] Y. Wang, J.K. Salazar, Culture-Independent Rapid Detection Methods for Bacterial Pathogens and Toxins in Food Matrices, Comprehensive Rev. Food Sci. Food Safety 15 (2016) 183-205.

[3] P. Arora, A. Sindhu, N. Dilbaghi, A. Chaudhury, Biosensors as innovative tools for the detection of food borne pathogens, Biosens. Bioelectron. 28 (2011) 1-12.

[4] I. Palchetti, M. Mascini, Electroanalytical biosensors and their potential for food pathogen and toxin detection, Anal. Bioanal. Chem. 391 (2008) 455-471. 
[5] L.V. Tarditto, M.A. Zon, Hugo García Ovando, N.R. Vettorazzi, F.J. Arévalo, H. Fernández, Electrochemical magneto immunosensor based on endogenous $\beta$ galactosidase enzyme to determine enterotoxicogenic Escherichia coli F4 (K88) in swine feces using square wave voltammetry, Talanta 174 (2017) 507-513.

[6] T. Zhang, J. Liu, C. Wang, X. Leng, Y. Xiao, L. Fu, Synthesis of graphene and related two-dimensional materials for bioelectronics devices, Biosens. Bioelectron. 89 (2017) 28-42.

[7] S. Mao, J. Chang, G. Zhou, J. Chen, Nanomaterial-enabled Rapid Detection of Water Contaminants, small 11 (2015) 5336-5359.

[8] F.H. Cincotto, G. Martínez-García, P. Yáñez-Sedeño, T.C. Canevari, S.A.S. Machado, J.M. Pingarrón, Electrochemica limmunosensor for ethinylestradiol using diazonium salt grafting onto silver nanoparticles-silica-graphene oxide hybrids, Talanta 147 (2016) 328-334.

[9] J. Chang, S. Mao, Y. Zhang, S. Cui, G. Zhou, X. Wu, C.-H. Yang, J. Chen, Ultrasonic-assisted self-assembly of monolayer graphene oxide for rapid detection of Escherichia coli bacteria, Nanoscale 5 (2013) 3620-3626.

[10] Y. Chen, Z.P. Michael, G.P. Kotchey, Y. Zhao, A. Star, Electronic Detection of Bacteria Using Holey Reduced Graphene Oxide, ACS Appl. Mater. Interfaces 6 (2014) 3805-3810.

[11] Y. Huang, X. Dong, Y. Liu, L.-J. Li, P. Chen, Graphene-based biosensors for detection of bacteria and their metabolic activities, J. Mater. Chem. 21 (2011) 1235812362.

[12] J. Jiang, X. Wang, R. Chao, Y. Ren, C. Hu, Z. Xu, G.L. Liu, Smartphone based portable bacteria pre-concentrating microfluidicsensor and impedance sensing, Sens. Actuators B 193 (2014) 653-659.

[13] N. Li, A. Brahmendra, A.J. Veloso, A. Prashar, X.R. Cheng, V.W.S. Hung, C. Guyard, M. Terebiznik, K. Kerman, Disposable immunochips for the detection of Legionella pneumophila using electrochemical impedance spectroscopy, Anal. Chem. 84 (2012) 3485-3488.

[14] C. Ruan, L. Yang, Y. Li, Immunobiosensor chips doe detection of Escherichia coli O157:H7 using electrochemical impedance spectroscopy, Anal. Chem. 74 (2002) 4814-4820. 
[15] M. Tichoniuk, D. Gwiazdowska, M. Ligaj, M. Filipiak, Electrochemical detection of foodborne pathogen Aeromonas hydrophila by DNA hybridization biosensor, Biosens. Biolelectron. 26 (2010) 1618-1623.

[16] R. Wang, W. Dong, C. Ruan, D. Kanayeva, R. Tian, K. Lassiter, Y. Li, TiO2 nanowire bundle microelectrode based impedance immunosensor for rapid and sensitive detection of Listeria monocytogenes, Nano Lett. 9 (2008) 2625-2631.

[17] L. Yang, C. Ruan, Y. Li, Detection of viable Salmonella typhimurium by impedance measurement of electrode capacitance and medium resistance, Biosens. Bioelectron. 19 (2003) 495-502.

[18] Y. Wan, Z. Lin, D. Zhang, Y. Wang, B. Hou, Impedimetric immunosensor doped with reduced graphene sheets fabricated by controllable electrodeposition for the nonlabelled detection of bacteria, Biosens. Bioelectron. 26 (2011) 1959-1964.

[19] A. Ahmed, J.V. Rushworth, J.D. Wright, P.A. Millner, Novel impedimetric immunosensor for detection of pathogenic bacteria Streptococcus pyogenes in human saliva, Anal. Chem. 85 (2013) 12118-12125.

[20] Y.S. Grewal, M.J.A. Shiddiky, S.A. Gray, K.M. Weigel, G.A. Cangelosi, M. Trau, Label-free electrochemical detection of an Entamoeba histolytica antigen using cell-free yeast-scFv probes, Chem. Commun. 49 (2013) 1551-1553.

[21] C. Tlili, E. Sokullu, M. Safavieh, M. Tolba, M.U. Ahmed, M. Zourob, Bacteria screening, viability, and confirmation assays using bacteriophage-impedimetric/loopmediated isothermal amplification dual-response biosensors, Anal. Chem. 85 (2013) 4893-4901.

[22] C. Zhu, G. Yang, H. Li, D. Du, Y. Lin, Electrochemical Sensors and Biosensors Based on Nanomaterials andNanostructures, Anal. Chem. 87 (2015) 230-249.

[23] C.M. Pandey, I. Tiwari, V.N. Singh, K.N. Sood, G. Sumana, B.D. Malhotra, Highly sensitive electrochemical immunosensor based on graphene-wrapped copper oxide-cysteine hierarchical structure for detection of pathogenic bacteria, Sens. Actuators B 238 (2017) 1060-1069.

[24] P. Subramanian, F. Barka-Bouaifel, J. Bouckaert, N. Yamakawa, R. Boukherroub, S. Szunerits, Graphene-Coated Surface Plasmon Resonance Interfaces for Studying the Interactions between Bacteria and Surfaces, ACS Appl. Mater. Interfaces 6 (2014) 5422-5431.

[25] P. Subramanian, A. Lesniewski, I. Kaminska, A. Vlandas, A. Vasilescu, J. Niedziolka-Jonsson, E. Pichonat, H. Happy, R. Boukherroub, S. Szunerits, Lysozyme 
detection on aptamer functionalized graphene-coated SPR interfaces, Biosens. Bioelectron. 50 (2013) 239-243.

[26] S.J. An, Y.W. Zhu, S.H. Lee, M.D. Stoller, T. Emilsson, S. Park, A. Velamakanni, J.H. An, R.S. Ruoff, Thin Film Fabrication and Simultaneous Anodic Reduction of Deposited Graphene Oxide Platelets by Electrophoretic Deposition, J. Phys. Chem. Lett. 1 (2012) 1259-1263.

[27] A. Pandey, Y. Gurbuz, V. Ozguz, J.H. Niazi, A. Qureshi, Graphene-interfaced electrical biosensor for label-free and sensitivedetection of foodborne pathogenic $E$. coli O157:H7, Biosens. Bioelectron. 91 (2017) 225-231.

[28] R. Hernandez, C. Valles, A.M. Benito, W.K. Maser, F.X. Rius, J. Riu, Graphenebased potentiometric biosensor for the immediate detection of living bacteria, Biosens. Bioelectron. 54 (2014) 553-557. 